\title{
A europium(III) metal-organic framework as ratiometric turn-on luminescent sensor for $\mathrm{Al}^{3+}$ ions
}

\author{
Xinhui Zhou ${ }^{1 *}$, Jiahui Cheng ${ }^{1}$, Liang Li $^{1}$, Qiang Chen ${ }^{1}$, Yujian You ${ }^{1}$, Hongping Xiao ${ }^{2}$ and \\ Wei Huang ${ }^{1,3^{*}}$
}

In recent years, luminescent metal-organic frameworks (MOFs) as a new type of sensing material are receiving enormous attention for their superior performance in chemical sensors and biosensors [1-2]. Taking account of the excellent optical properties such as large Stokes shifts and high color purity of lanthanide MOFs (LnMOFs), a great deal of important investigations on LnMOFs have been carried out. And then, their promising abilities in detecting temperature, metal ions, oxygen, explosives and polychlorizated benzenes with high sensitivity and selectivity have also been exploited successfully [3-22]. Ratiometric luminescent sensors can provide a self-calibrated analyte concentration readout, which is unaffected by fluctuations of sensor concentration and/or instrumental parameters. However, it is noticed that a majority of related reports are limited to the detection of analyte using single emission, although ratiometric sensors based on dual-emission are more reliable and accurate than the sensors based on single emission. For ratiometric sensors, not only are two significantly different emissions necessary, but two emissions need distinctive response to the analyte. From this point of view, LnMOFs with ligand and $\mathrm{Ln}^{3+}$ emissions are very attractive, because organic ligands and $\mathrm{Ln}^{3+}$ ions as the luminescent centers possess completely different physical and chemical properties and they would produce different interactions with analytes. Thus, LnMOFs have been extensively applied to construct ratiometric sensors recently $[3,22]$.

Aluminium exists in soil, containers and structural materials, which may release $\mathrm{Al}^{3+}$ due to the corrosion and/or dissolvation, inducing the increasing risk of $\mathrm{Al}^{3+}$ absorption by the human body [23-27]. However, excessive $\mathrm{Al}^{3+}$ in human body may cause damage to nucleic acids and proteins or the central nervous system [28-30]. Thus, it is important to detect $\mathrm{Al}^{3+}$ with high selectivity and sensitivity, both in the environment and organisms $[31,32]$. As far as we are concerned, few LnMOFs display high selectivity and sensitivity for $\mathrm{Al}^{3+}$ [33-35]. It is noted that $\mathrm{Al}^{3+}$ may replace the $\mathrm{Ln}^{3+}$ in the framework or interact with the ligands [36]. As a consequence, both ligand and $\mathrm{Ln}^{3+}$ emissions may be interfered by $\mathrm{Al}^{3+}$ ions. These facts impel us to realize LnMOFs ratiometric sensors for $\mathrm{Al}^{3+}$ by the judicious choice of the organic ligand. Recently, a few works reported different fluorescence response behavior to $\mathrm{Al}^{3+}$ ions for the emissions of the ligand and $\mathrm{Tb}^{3+}$ ion $[37,38]$. In these cases, the $\mathrm{Tb}^{3+}$ emission decreases gradually, whereas the ligand emission shows a strong enhancement as the addition of $\mathrm{Al}^{3+}$ ions. Inspired by these cases, we aimed to synthesize LnMOFs as ratiometric luminescent sensors to detect $\mathrm{Al}^{3+}$ ions.

In this work, three Ln-MOFs, $\left(\mathrm{Me}_{2} \mathrm{NH}_{2}\right)\left[\mathrm{Ln}_{2} \mathrm{~L}_{2}\left(\mathrm{NO}_{3}\right)_{2}\right.$ $\left.\left(\mu_{3}-\mathrm{OH}\right)\left(\mathrm{H}_{2} \mathrm{O}\right)\right] \cdot 2 \mathrm{H}_{2} \mathrm{O} \cdot 2 \mathrm{DMA},[\mathrm{Ln}=\mathrm{Eu}(\mathbf{1}), \mathrm{Gd}(\mathbf{2})$ and $\mathrm{Tb}$ (3), DMA=dimethylacetamide], were obtained based on a robust ligand, 9-methyl-9-hydroxy-fluorene-2,7-dicarboxylic acid $\left(\mathrm{H}_{2} \mathrm{~L}\right)$, which can effectively transfer energy to $\mathrm{Eu}^{3+}$ by antenna effect. All frameworks are isostructural, and the topology analysis of frameworks shows a uninodal 8-connected body centered cubic (bcu) network. The luminescence investigations reveal that $\mathbf{1}$ is a LnMOF ratiometric sensor for $\mathrm{Al}^{3+}$ with high sensitivity and selectivity.

Compounds 1-3 were synthesized in the mixed sol-

\footnotetext{
${ }^{1}$ Key Laboratory for Organic Electronics and Information Displays \& Jiangsu Key Laboratory for Biosensors, Institute of Advanced Materials (IAM), Jiangsu National Synergetic Innovation Center for Advanced Materials (SICAM), Nanjing University of Posts \& Telecommunications, Nanjing 210023, China

${ }^{2}$ College of Chemistry and Materials Engineering, Wenzhou University, Wenzhou 325035, China

${ }^{3}$ Key Laboratory of Flexible Electronics (KLOFE) \& Institute of Advanced Materials (IAM), Jiangsu National Synergetic Innovation Center for Advanced Materials (SICAM), Nanjing Tech University, Nanjing 211816, China

* Corresponding authors (emails: iamxhzhou@njupt.edu.cn (Zhou X); iamwhuang@njtech.edu.cn (Huang W))
} 
vents under solvothermal conditions. Due to the poor crystal qualities, X-ray single-crystal diffraction data for $\mathbf{2}$ were not obtained. However, powder X-ray diffraction (PXRD) data, thermogravimetric analysis (TG) and infrared spectroscopy (IR) confirm that $\mathbf{2}$ is isostructural with 1 and 3 (Figs S1-S3). They are stable in air but unstable in water, and their stabilities in dimethylformamide (DMF), ethyl acetate (EA), ethyl alcohol (EtOH), $N$-methyl pyrrolidone (NMP) are also verified by PXRD of 1 dipped in these solvents for $24 \mathrm{~h}$. As shown in Fig. S2, the presence of $\mathrm{H}_{2} \mathrm{O}$ molecules and $-\mathrm{CH}_{3}$ is confirmed by the characteristic bands of $\mathrm{O}-\mathrm{H}$ $\left(3,680-3,000 \mathrm{~cm}^{-1}\right)$ and $\mathrm{C}-\mathrm{H}\left(2,900-3,000 \mathrm{~cm}^{-1}\right)$ vibrations, respectively. Since no strong absorption peaks ranging from 1,690 to $1,730 \mathrm{~cm}^{-1}$ for $-\mathrm{COOH}$ are observed, and the characteristic sharp bands of carboxylate groups appear with the maxima at 1,544 and $1,381 \mathrm{~cm}^{-1}$ for $1,1,550$ and $1,384 \mathrm{~cm}^{-1}$ for $2,1,553$ and $1,381 \mathrm{~cm}^{-1}$ for 3, all carboxyl groups for $\mathrm{H}_{2} \mathrm{~L}$ ligands in complexes 1-3 should be deprotonated.

Since 1-3 are isostructural, $\mathbf{1}$ is selected as the representative example to describe the structure in detail. The asymmetric unit of $\mathbf{1}$ includes a $\mathrm{L}^{2-}$ ligand, half a coordinated $\mathrm{H}_{2} \mathrm{O}$, a free $\mathrm{H}_{2} \mathrm{O}$, half a $\mu_{3}-\mathrm{OH}^{-}$, a coordinated $\mathrm{NO}_{3}^{-}$, a free DMA, half a free $\mathrm{Me}_{2} \mathrm{NH}_{2}{ }^{+}$and two crystallographically unique $\mathrm{Eu}^{3+}$ ions, of which $\mathrm{Eu} 1$ lies on the mirror plane parallel with $a b$ crystal plane and Eu2 on the twofold axis parallel with $c$ axis (Fig. 1a). Eu1 and Eu2 are coordinated by oxygen atoms with tricapped and bicapped trigonal prismatic coordination geometry, respectively. Four $\mathrm{Eu}^{3+}$ ions, two $\mu_{3}-\mathrm{OH}^{-}$and four carboxylate oxygens form face-sharing defective cubes-like $\mathrm{Eu}_{4} \mathrm{O}_{6}$ metal-oxygen cluster. Each $\mathrm{L}^{2-}$ ligand bridges two $\mathrm{Eu}_{4} \mathrm{O}_{6}$ clusters and each $\mathrm{Eu}_{4} \mathrm{O}_{6}$ cluster is coordinated by eight $\mathrm{L}^{2-}$ ligands (Fig. 1b). The resulting three-dimensional framework possesses rhombic channels extended along the [010] direction with $14 \times 20 \AA^{2}$ diagonally dimensions in which $\mathrm{H}_{2} \mathrm{O}, \mathrm{NO}_{3}{ }^{-}, \mathrm{Me}_{2} \mathrm{NH}_{2}{ }^{+}$and DMA locate as guests and counterions (Fig. 1c, d). The solvent accessible space for $\mathbf{1}$ without these guests and counterions is $4,319 \AA^{3}$ per unit cell or $65 \%$ of the total volume, calculated using the PLATON routine [39]. The 3D framework can be rationalized by the TOPOS 4.0 program [40] as a uninodal 8-connected bcu topological network with a Schläfli symbol of $4^{24} \cdot 6^{4}$ by considering the $\mathrm{Eu}_{4} \mathrm{O}_{6}$ clusters as 8 -connected nodes and $\mathrm{L}^{2-}$ ligands as linkers, respectively.

Powder 1-3 were heated up to $800^{\circ} \mathrm{C}$ in $\mathrm{N}_{2}$ atmosphere at a heating rate of $10^{\circ} \mathrm{C} \mathrm{min}^{-1}$. The TG curves show that 1-3 undergo similar weight loss processes (Fig. S3). In the

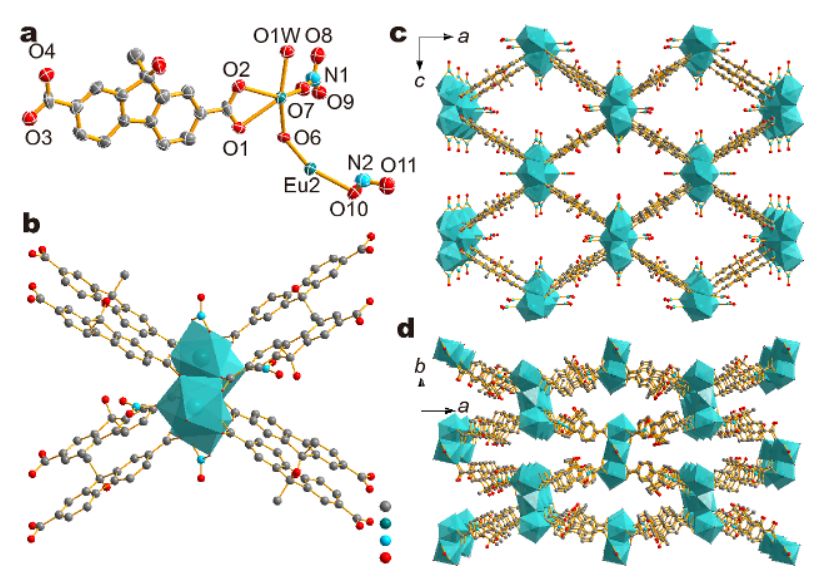

Figure 1 (a) View of the asymmetric unit of 1 with the thermal ellipsoids drawn at the $50 \%$ probability level. (b) View of $\mathrm{Eu}_{4} \mathrm{O}_{6}$ metaloxygen cluster. View of crystal structure of 1 along the $b$-axis (c) and $c$ axis (d). All hydrogen atoms, $\mathrm{Me}_{2} \mathrm{NH}_{2}{ }^{+}$, uncoordinated water and DMA molecules are omitted for clarity.

temperature range of $20-110^{\circ} \mathrm{C}$, the weight losses of $1-3$ are $3.9 \%, 2.3 \%$ and $2.2 \%$, respectively, corresponding to the departure of all water molecules for $\mathbf{1}$ and two lattice water molecules for $\mathbf{2}$ and $\mathbf{3}$ (calc. $4.2 \%, 2.8 \%, 2.8 \%$ ). The weight loss of $16.5 \%, 19.1 \%$ and $18.3 \%$ in the range of $110-245^{\circ} \mathrm{C}$ for $\mathbf{1}-\mathbf{3}$ is attributed to the departure of two DMA, a $\mathrm{Me}_{2} \mathrm{NH}_{2}^{+}$for 1, two DMA, a $\mathrm{Me}_{2} \mathrm{NH}_{2}^{+}$and a coordinated water molecule for 2 and 3 (calc. 17.2\%, $18.5 \%, 18.3 \%)$. Further heating leads to the decomposition of ligand molecules. The PXRD patterns of 1-3 are shown in Fig. S1. The experimental XRD patterns of the synthesized 1-3 are in good agreement with the simulated, showing the good phase purity.

The photoluminescence spectra of $\mathbf{1 - 3}$ in solid state are shown in Fig. S4a. Upon excitation at $335 \mathrm{~nm}$, the emission spectrum of 1 reveals a weak emission band with intensity maximum at $362 \mathrm{~nm}\left(\mathrm{~S}_{1} \rightarrow \mathrm{S}_{0}\right.$ transition), and characteristic emission peaks of $\mathrm{Eu}^{3+}$ at $596\left({ }^{5} \mathrm{D}_{0} \rightarrow{ }^{7} \mathrm{~F}_{1}\right.$ transition) and $620 \mathrm{~nm}\left({ }^{5} \mathrm{D}_{0} \rightarrow{ }^{7} \mathrm{~F}_{2}\right.$ transition). The decay curve of the ${ }^{5} \mathrm{D}_{0} \rightarrow{ }^{7} \mathrm{~F}_{2}$ transition of $\mathbf{1}$ was best fitted by a second order exponential function with lifetimes $\tau_{1}=$ $302.54 \mu \mathrm{s}\left(\alpha_{1}=3.95 \%\right)$ and $\tau_{2}=771.67 \mu \mathrm{s}\left(\alpha_{2}=96.05 \%\right)$ (Fig. S4b). Quantum yield of 1 is $40.6 \% .2$ exhibits a ligand-based emission centered at $368 \mathrm{~nm}$. The triplet state energy $\left(\mathrm{T}_{1}\right)$ and the singlet state energy $\left(\mathrm{S}_{1}\right)$ of ligand are estimated as $20,533 \mathrm{~cm}^{-1}$ and $25,974 \mathrm{~cm}^{-1}$ from the $77 \mathrm{~K}$ phosphorescence spectrum (Fig. S5) and the absorption spectrum (Fig. S6) of $\mathbf{2}$. 3 exhibits a strong ligand-based emission band centered at $365 \mathrm{~nm}$ and weak characteristic emission peaks of $\mathrm{Tb}^{3+}$ ions at 494 and $550 \mathrm{~nm}$. The blue-shift of ligand-centered emission ob- 

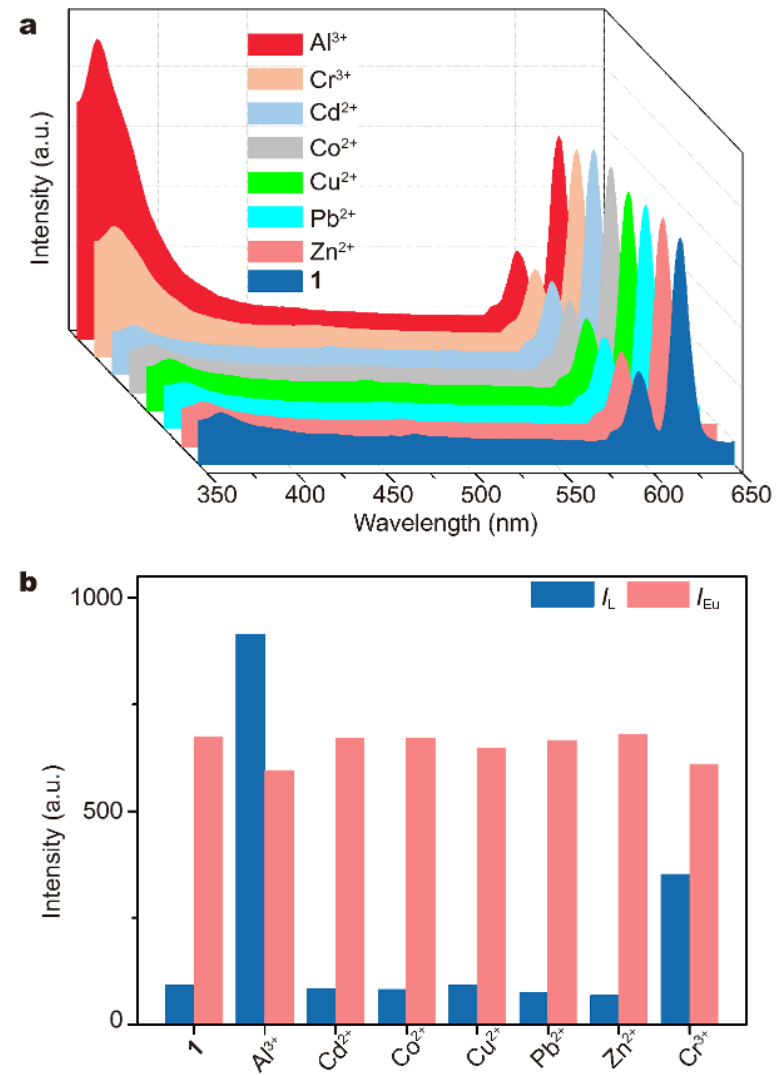

Figure 2 (a) Upon excitation at $335 \mathrm{~nm}$, the photoluminescence spectra of 1 treated with different metal ions $\left(1 \times 10^{-4} \mathrm{~mol} \mathrm{~L}^{-1}\right)$ in DMF and (b) the corresponding emission intensities of ${ }^{5} \mathrm{D}_{0} \rightarrow{ }^{7} \mathrm{~F}_{2}$ transition ( $I_{\mathrm{Eu}}$, $620 \mathrm{~nm})$ and $\mathrm{S}_{1} \rightarrow \mathrm{S}_{0}\left(I_{\mathrm{L}}, 362 \mathrm{~nm}\right)$ of $\mathbf{1}$.

served for 1-3, compared to that of $\mathrm{H}_{2} \mathrm{~L}$ itself [13] $(412 \mathrm{~nm})$, may be attributed to the torsion of ligand when coordinating to the metal ion.

The excellent luminescence property of $\mathbf{1}$ promoted us to develop its ability as luminescent sensing material. Detection of various metal ions $\left(\mathrm{Cd}^{2+}, \mathrm{Co}^{2+}, \mathrm{Cu}^{2+}, \mathrm{Pb}^{2+}\right.$, $\mathrm{Zn}^{2+}, \mathrm{Al}^{3+}$ and $\mathrm{Cr}^{3+}$ ) was performed by collecting the change in fluorescence spectra of 1 suspension in DMF ( $3 \mathrm{mg}$ per $3 \mathrm{~mL}$ ) before and after addition of the metal ions with the concentration of $1 \times 10^{-4} \mathrm{~mol} \mathrm{~L}^{-1}$. The luminescent spectra are shown in Fig. 2. The results reveal that most metal ions do not show obvious change on luminescence intensity for both the ligand-centered emission and $\mathrm{Eu}^{3+}$ ion emission. However, among the metal ions studied, the influence of $\mathrm{Cr}^{3+}$ and $\mathrm{Al}^{3+}$ ions on the emissions of $\mathbf{1}$ are highly pronounced, particularly for $\mathrm{Al}^{3+}$ ions, suggesting that $\mathbf{1}$ possesses a good luminescent sensing selectivity for $\mathrm{Al}^{3+}$ ions. The $\mathrm{Al}^{3+}$ ion increases dramatically the ligand-centered emission intensity by
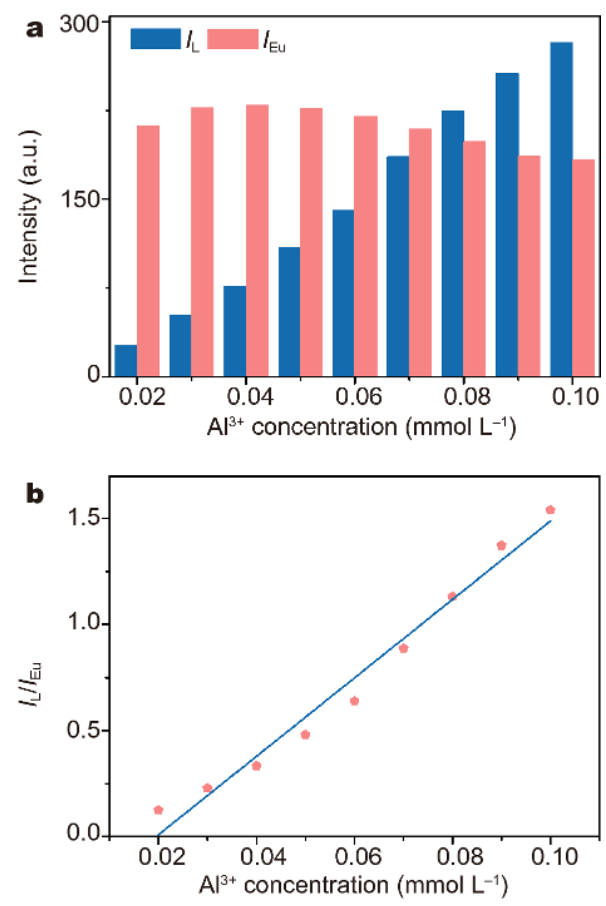

Figure $3 I_{\mathrm{L}}(362 \mathrm{~nm})$ and $I_{\mathrm{Eu}}(620 \mathrm{~nm})(\mathrm{a})$, and the intensity ratio of $I_{\mathrm{L}}$ to $I_{\mathrm{Eu}}(\mathrm{b})$ of 1 treated in different concentrations of $\mathrm{Al}^{3+}$ in $\mathrm{DMF}$.

approximately $880 \%$ simultaneously with a subtle change in $\mathrm{Eu}^{3+}$ ion emission intensity.

To have a better understanding of the luminescence response of 1 to $\mathrm{Al}^{3+}$ ions, photoluminescence titration experiments were further conducted. As the concentrations of $\mathrm{Al}^{3+}$ increase from $0.2 \times 10^{-4}$ to $1 \times 10^{-4} \mathrm{~mol} \mathrm{~L}^{-1}$, the ligand-centered emission intensities progressively increase whereas the $\mathrm{Eu}^{3+}$ ion emission keeps almost constant (Fig. 3a). The intensity of emission at $620 \mathrm{~nm}$ is seven times higher than that at $362 \mathrm{~nm}$ without the presence of $\mathrm{Al}^{3+}$ ions. However, when the concentration of the $\mathrm{Al}^{3+}$ ions reaches $1 \times 10^{-4} \mathrm{~mol} \mathrm{~L}{ }^{-1}$, the intensity of emission at $362 \mathrm{~nm}$ is 1.6 times bigger than that at $620 \mathrm{~nm}$. Ratiometric luminescent sensors based on dualemission provide a self-calibrated data readout, and are more reliable and accurate than those based on a single emission intensity. In this work, the intensity ratio of emissions at 362 and $620 \mathrm{~nm}$ changes with the $\mathrm{Al}^{3+}$ ion concentration, which encourage us to check whether or not $\mathbf{1}$ can be used as ratiometric luminescent sensor for the detection of $\mathrm{Al}^{3+}$ ions. So we carefully examined the photoluminescence titration experimental data and tried to find the law of relationship between the emission intensity ratio of $\mathrm{S}_{1} \rightarrow \mathrm{S}_{0}\left(I_{\mathrm{L}}\right)$ to ${ }^{5} \mathrm{D}_{0} \rightarrow{ }^{7} \mathrm{~F}_{2}$ transition $\left(I_{\mathrm{Eu}}\right)$ and $\mathrm{Al}^{3+}$ ion concentration. As shown in Fig. $3 \mathrm{~b}$, the $\mathrm{Al}^{3+}$ ion 


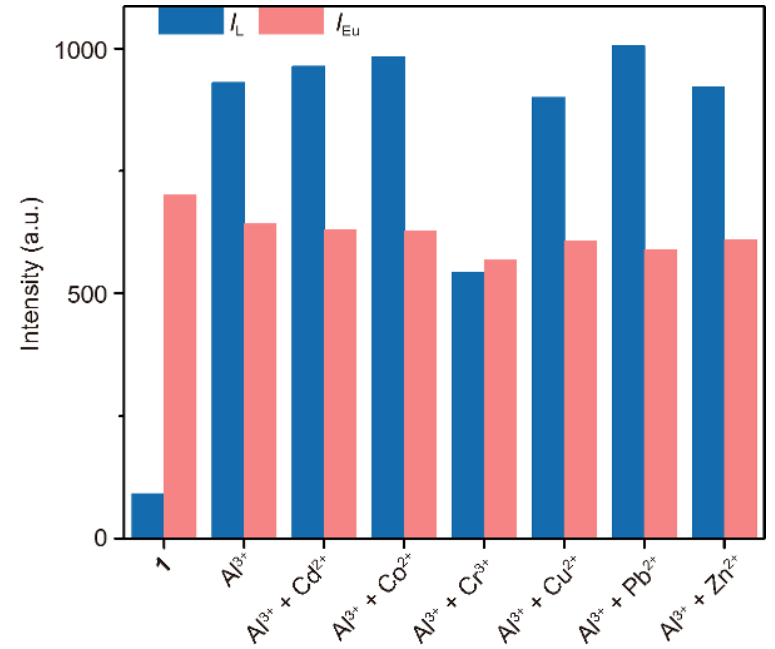

Figure 4 The $I_{\mathrm{L}}(362 \mathrm{~nm})$ and $I_{\mathrm{Eu}}(620 \mathrm{~nm})$ of 1 treated in mixed metal ions.

concentration can be linearly related to $I_{\mathrm{L}} / I_{\mathrm{Eu}}$ by the equation $I_{\mathrm{L}} / I_{\mathrm{Eu}}=k\left[\mathrm{Al}^{3+}\right]-0.36\left(k=18,502 \mathrm{~L} \mathrm{~mol}^{-1}, R^{2}=\right.$ 0.98 ), from $0.2 \times 10^{-4}$ to $1 \times 10^{-4} \mathrm{~mol} \mathrm{~L}^{-1}$. The limit of detection of $\mathbf{1}$ for $\mathrm{Al}^{3+}$ ions is calculated as $1.30 \times 10^{-6} \mathrm{~mol}$ $\mathrm{L}^{-1}$, indicating that $\mathbf{1}$ is an excellent candidate of the ratiometric luminescent $\mathrm{Al}^{3+}$ ion sensor. In addition, we have investigated the recyclability of sensing performance of 1. Unfortunately, this material shows a poor recyclability for sensing performance (Fig. S7).

The high selectivity of $\mathbf{1}$ for $\mathrm{Al}^{3+}$ sensing was further confirmed by competitive experiments, which was conducted by adding a interferential metal ion $\left(1 \times 10^{-4} \mathrm{~mol} \mathrm{~L}^{-1}\right)$ into the $\mathbf{1}$ suspension containing $1 \times 10^{-4} \mathrm{~mol} \mathrm{~L}^{-1} \mathrm{Al}^{3+}$ in DMF. As shown in Fig. 4, the ligand-based emission exhibits similar degree of enhancement with a subtle change in $\mathrm{Eu}^{3+}$ ion emission intensity before and after introduction of $\mathrm{Cd}^{2+}, \mathrm{Co}^{2+}, \mathrm{Cu}^{2+}$, $\mathrm{Pb}^{2+}$ or $\mathrm{Zn}^{2+}$, suggesting that these metal ions in solution would not influence the detection for $\mathrm{Al}^{3+}$. However, for $\mathrm{Cr}^{3+}$ ions, a smaller enhancement in the ligand-based emission was observed, revealing that the detection for $\mathrm{Al}^{3+}$ can be interfered by $\mathrm{Cr}^{3+}$ because $\mathrm{Cr}^{3+}$ and $\mathrm{Al}^{3+}$ possess +3 charge while other metal ions possess +2 charge and the radius of $\mathrm{Cr}^{3+}(0.0615 \mathrm{~nm})$ is closer to that of $\mathrm{Al}^{3+}(0.0535 \mathrm{~nm})$ relative to that of other metal ions $(>0.065 \mathrm{~nm})$.

According to previous reports, the enhancement effect on ligand-based fluorescence of MOFs by $\mathrm{Al}^{3+}$ or $\mathrm{Cr}^{3+}$ may be attributed to the following factors: (a) cationexchange between $\mathrm{Ln}^{3+}$ of framework and $\mathrm{Al}^{3+}$ or $\mathrm{Cr}^{3+}$ and (b) interaction between ligand and $\mathrm{Al}^{3+}$ or $\mathrm{Cr}^{3+}$. Several
$\mathrm{Al}^{3+}$ sensors of MOF materials based on the former have been reported. The first example was described in 2013 by Sun et al. [30], who used compound $\left[\mathrm{H}_{2} \mathrm{~N}\left(\mathrm{CH}_{3}\right)_{2}\right]$ $\left[\mathrm{Eu}\left(\mathrm{H}_{2} \mathrm{O}\right)_{2}(\mathrm{BTMIPA})\right] \cdot 2 \mathrm{H}_{2} \mathrm{O}\left(\mathrm{H}_{4} \mathrm{BTMIPA}=5,5^{\prime}\right.$-methylenebis(2,4,6-trimethylisophthalic acid)) to detect the $\mathrm{Al}^{3+}$. The authors observed that ligand emission increased and the compounds dissolved gradually leading to the clear solution due to $\mathrm{Al}^{3+}$ substituting $\mathrm{Ln}^{3+}$ in the framework when $\mathrm{Al}^{3+}$ concentration was greater than $0.001 \mathrm{~mol} \mathrm{~L}^{-1}$ and the framework of the compound collapsed completely when the $\mathrm{Al}^{3+}$ concentration reached $0.01 \mathrm{~mol} \mathrm{~L}^{-1}$. However, we found that 1 suspension in DMF containing $\mathrm{Al}^{3+}$ kept turbid and strong characteristic red light emission of $\mathrm{Eu}^{3+}$ ions after 1 dipped in DMF containing $1 \times 10^{-4} \mathrm{~mol} \mathrm{~L}^{-1}$ and $1 \times 10^{-5} \mathrm{~mol} \mathrm{~L}^{-1} \mathrm{Al}^{3+}$ for $12 \mathrm{~h}$, respectively, as shown in Fig. S8, which indicate that cation-exchange do not contribute to ligand-based fluorescence enhancement in this work. So, we speculated that the interactions between ligand and $\mathrm{Al}^{3+}$ or $\mathrm{Cr}^{3+}$ lead to the ligand-based fluorescence enhancement, and the luminescence spectra of the $\mathrm{H}_{2} \mathrm{~L}$ (9-methyl-9-hydroxyfluorene-2,7-dicarboxylic acid) and $\mathrm{H}_{2}$ MFDC (9,9'-dimethyl-fluorene-2,7-dicarboxylic acid) solutions in DMF before and after addition of $\mathrm{Al}^{3+}$ or $\mathrm{Cr}^{3+}\left(1 \times 10^{-4} \mathrm{~mol} \mathrm{~L}^{-1}\right)$ were investigated. The $\mathrm{H}_{2} \mathrm{~L}$ and $\mathrm{H}_{2} \mathrm{MFDC}$ are two very similar ligands with a marginal difference, a methyl and a hydroxy on 9-position for $\mathrm{H}_{2} \mathrm{~L}$, two methyl on 9-position for $\mathrm{H}_{2}$ MFDC. As shown in Figs $\mathrm{S} 9$ and $\mathrm{S} 10$, when $\mathrm{Al}^{3+}$ or $\mathrm{Cr}^{3+}$ was added to the solution, the emission intensity of $\mathrm{H}_{2} \mathrm{~L}$ increases while the intensity of $\mathrm{H}_{2}$ MFDC remains unchanged. It is a very powerful suggestion that the interactions between the hydroxyl on the 9-position of $\mathrm{H}_{2} \mathrm{~L}$ and $\mathrm{Al}^{3+}$ or $\mathrm{Cr}^{3+}$ are the essential factor for ligand-based fluorescence enhancement. Furthermore, the enhancement effect is more pronounced for the LnMOF 1 than free $\mathrm{H}_{2} \mathrm{~L}$, illustrating that the coordination between $\mathrm{Eu}^{3+}$ and $\mathrm{H}_{2} \mathrm{~L}$ plays the important role in signal amplification. Based on the above results, we proposed that the hydroxyl on the 9-position of ligand in the $\mathbf{1}$ interacts with $\mathrm{Al}^{3+}$ or $\mathrm{Cr}^{3+}$ to reduce the vibration of $\mathrm{O}-\mathrm{H}$, which effectively inhibits nonradiative $S_{1}$ transition and results in the ligand emission enhancement.

In summary, we have obtained three isostructural LnMOFs ( $\mathrm{Eu}(\mathbf{1}), \mathrm{Gd}(\mathbf{2}), \mathrm{Tb}(\mathbf{3}))$ based on 9-methyl-9-hydroxy-fluorene-2,7-dicarboxylic acid $\left(\mathrm{H}_{2} \mathrm{~L}\right)$. In 1-3, the face-sharing defective cubes-like $\mathrm{Eu}_{4} \mathrm{O}_{6}$ metal-oxygen clusters as 8-connected nodes construct the body centered cubic topological network with a Schläfli symbol of $4^{24} \cdot 6^{4}$. The unique luminescence feature gives 1 the ability to detect the $\mathrm{Al}^{3+}$ ions by the ratiometric luminescent 
approach with slope of $18,502 \mathrm{~mol} \mathrm{~L}^{-1}$. We have also demonstrated that interactions between the $-\mathrm{OH}$ on the 9-position of ligand and $\mathrm{Al}^{3+}$ ions contribute to the sensing behavior. Our future work will be continually focused on the development and optimization of ratiometric luminescent sensors for other toxic metal ions.

\section{Received 23 October 2017; accepted 19 December 2017;} published online 10 January 2018

1 Allendorf MD, Bauer CA, Bhakta RK, et al. Luminescent metalorganic frameworks. Chem Soc Rev, 2009, 38: 1330-1352

2 Cui Y, Yue Y, Qian G, et al. Luminescent functional metal-organic frameworks. Chem Rev, 2012, 112: 1126-1162

3 Rocha J, Brites CDS, Carlos LD. Lanthanide organic framework luminescent thermometers. Chem Eur J, 2016, 22: 14782-14795

4 Li L, Zhu Y, Zhou X, et al. Visible-light excited luminescent thermometer based on single lanthanide organic frameworks. Adv Funct Mater, 2016, 26: 8677-8684

5 Cui Y, Xu H, Yue Y, et al. A luminescent mixed-lanthanide metalorganic framework thermometer. J Am Chem Soc, 2012, 134: 3979-3982

6 Cui Y, Song R, Yu J, et al. Dual-emitting mofวdye composite for ratiometric temperature sensing. Adv Mater, 2015, 27: 1420-1425

7 Hu Z, Deibert BJ, Li J. Luminescent metal-organic frameworks for chemical sensing and explosive detection. Chem Soc Rev, 2014, 43: 5815-5840

8 Li L, Chen Q, Niu Z, et al. Lanthanide metal-organic frameworks assembled from a fluorene-based ligand: selective sensing of $\mathrm{Pb}^{2+}$ and $\mathrm{Fe}^{3+}$ ions. J Mater Chem C, 2016, 4: 1900-1905

9 Liu B, Hou L, Wu WP, et al. Highly selective luminescence sensing for $\mathrm{Cu}^{2+}$ ions and selective $\mathrm{CO}_{2}$ capture in a doubly interpenetrated MOF with Lewis basic pyridyl sites. Dalton Trans, 2015, 44: 44234427

10 Hao JN, Yan B. A water-stable lanthanide-functionalized MOF as a highly selective and sensitive fluorescent probe for $\mathrm{Cd}^{2+}$. Chem Commun, 2015, 51: 7737-7740

11 Dou Z, Yu J, Cui Y, et al. Luminescent metal-organic framework films as highly sensitive and fast-response oxygen sensors. J Am Chem Soc, 2014, 136: 5527-5530

$12 \mathrm{Hu} \mathrm{Z}$, Tan K, Lustig WP, et al. Effective sensing of RDX via instant and selective detection of ketone vapors. Chem Sci, 2014, 5: 48734877

13 Li A, Li L, Lin Z, et al. Guest-induced reversible structural transitions and concomitant on/off luminescence switching of an $\mathrm{Eu}(\mathrm{III})$ metal-organic framework and its application in detecting picric acid. New J Chem, 2015, 39: 2289-2295

14 Wang L, Fan G, Xu X, et al. Detection of polychlorinated benzenes (persistent organic pollutants) by a luminescent sensor based on a lanthanide metal-organic framework. J Mater Chem A, 2017, 5: 5541-5549

15 Cheng T, Hu J, Zhou C, et al. Luminescent metal-organic frameworks for nitro explosives detection. Sci China Chem, 2016, 59: 929-947

16 Zhou J, Li H, Zhang $\mathrm{H}$, et al. A bimetallic lanthanide metal-organic material as a self-calibrating color-gradient luminescent sensor. Adv Mater, 2015, 27: 7072-7077
17 Zhang SY, Shi W, Cheng P, et al. A mixed-crystal lanthanide zeolite-like metal-organic framework as a fluorescent indicator for lysophosphatidic acid, a cancer biomarker. J Am Chem Soc, 2015, 137: 12203-12206

18 Zhao M, Yuan K, Wang Y, et al. Metal-organic frameworks as selectivity regulators for hydrogenation reactions. Nature, 2016, 539: 76-80

19 He L, Liu Y, Liu J, et al. Core-shell noble-metal@metal-organicframework nanoparticles with highly selective sensing property. Angew Chem Int Ed, 2013, 52: 3741-3745

20 Wang $\mathrm{T}$, Jia $\mathrm{Y}$, Chen $\mathrm{Q}$, et al. A new luminescent metal-organic framework for selective sensing of nitroaromatic explosives. Sci China Chem, 2016, 59: 959-964

21 Wang S, Ma R, Chen Z, et al. Solvent- and metal-directed lanthanide-organic frameworks based on pamoic acid: observation of slow magnetization relaxation, magnetocaloric effect and luminescent sensing. Sci China Chem, 2016, 59: 948-958

22 Li B, Wen HM, Cui Y, et al. Emerging multifunctional metalorganic framework materials. Adv Mater, 2016, 28: 8819-8860

23 Zhao M, Deng Z, Tang J, et al. 2-(1-Pyrenyl) benzimidazole as a ratiometric and "turn-on" fluorescent probe for iron(III) ions in aqueous solution. Analyst, 2016, 141: 2308-2312

24 Gupta VK, Jain AK, Maheshwari G. Aluminum(III) selective potentiometric sensor based on morin in poly(vinyl chloride) matrix. Talanta, 2007, 72: 1469-1473

25 Deng M, Wang S, Liang C, et al. A FRET fluorescent nanosensor based on carbon dots for ratiometric detection of $\mathrm{Fe}^{3+}$ in aqueous solution. RSC Adv, 2016, 6: 26936-26940

26 Patidar R, Rebary B, Bhadu GR, et al. Fluorescent carbon nanoparticles as label-free recognizer of $\mathrm{Hg}^{2+}$ and $\mathrm{Fe}^{3+}$ through effective fluorescence quenching in aqueous media. J Lumin, 2016, 173: 243-249

27 Diao Q, Ma P, Lv L, et al. A water-soluble and reversible fluorescent probe for $\mathrm{Al}^{3+}$ and $\mathrm{F}^{-}$in living cells. Sensor Actuat B-Chem, 2016, 229: 138-144

28 Pithadia AS, Lim MH. Metal-associated amyloid- $\beta$ species in Alzheimer's disease. Curr Opin Chem Biol, 2012, 16: 67-73

29 Gauthier E, Fortier I, Courchesne F, et al. Aluminum forms in drinking water and risk of Alzheimer's disease. Environ Res, 2000, 84: 234-246

30 Flaten TP. Aluminium as a risk factor in Alzheimer's disease, with emphasis on drinking water. Brain Res Bull, 2001, 55: 187-196

31 Fu Y, Jiang XJ, Zhu YY, et al. A new fluorescent probe for $\mathrm{Al}^{3+}$ based on rhodamine $6 \mathrm{G}$ and its application to bioimaging. Dalton Trans, 2014, 43: 12624-12632

32 Afshani J, Badiei A, Lashgari N, et al. A simple nanoporous silicabased dual mode optical sensor for detection of multiple analytes $\left(\mathrm{Fe}^{3+}, \mathrm{Al}^{3+}\right.$ and $\left.\mathrm{CN}^{-}\right)$in water mimicking XOR logic gate. RSC Adv, 2016, 6: 5957-5964

$33 \mathrm{Xu} \mathrm{XY,} \mathrm{Yan} \mathrm{B.} \mathrm{Eu(III)-functionalized} \mathrm{MIL-124} \mathrm{as} \mathrm{fluorescent}$ probe for highly selectively sensing ions and organic small molecules especially for Fe(III) and Fe(II). ACS Appl Mater Interfaces, 2015, 7: 721-729

34 Dong XY, Wang R, Wang JZ, et al. Highly selective $\mathrm{Fe}^{3+}$ sensing and proton conduction in a water-stable sulfonate-carboxylate Tb-organic-framework. J Mater Chem A, 2015, 3: 641-647

35 Liang YT, Yang GP, Liu B, et al. Four super water-stable lanthanide-organic frameworks with active uncoordinated carboxylic and pyridyl groups for selective luminescence sensing of $\mathrm{Fe}^{3+}$. Dalton Trans, 2015, 44: 13325-13330 
Chen Z, Sun Y, Zhang L, et al. A tubular europium-organic framework exhibiting selective sensing of $\mathrm{Fe}^{3+}$ and $\mathrm{Al}^{3+}$ over mixed metal ions. Chem Commun, 2013, 49: 11557-11559

37 Cao LH, Shi F, Zhang WM, et al. Selective sensing of $\mathrm{Fe}^{3+}$ and $\mathrm{Al}^{3+}$ ions and detection of 2,4,6-trinitrophenol by a water-stable terbium-based metal-organic framework. Chem Eur J, 2015, 21: 15705-15712

38 Zhang $\mathrm{M}$, Han $\mathrm{J}, \mathrm{Wu} \mathrm{H}$, et al. Tb-MOF: a naked-eye and regenerable fluorescent probe for selective and quantitative detection of $\mathrm{Fe}^{3+}$ and $\mathrm{Al}^{3+}$ ions. RSC Adv, 2016, 6: 94622-94628

39 Spek AL. Single-crystal structure validation with the program PLATON. J Appl Crystlogr, 2003, 36: 7-13

40 Blatov VA, O'Keeffe M, Proserpio DM. Vertex-, face-, point-, Schläfli-, and Delaney-symbols in nets, polyhedra and tilings: recommended terminology. CrystEngComm, 2010, 12: 44-48
Science Foundation of China (21271143), Priority Academic Program Development of Jiangsu Higher Education Institutions (PAPD) (YX03001), Jiangsu Province Double Innovation Talent Program (090300014001), Nanjing University of Posts \& Telecommunications (NY212004).

Conflict of interest The authors declare no competing financial interest.

Supplementary information Experimental section, tables of crystallographic data and selected bond lengths and angles, diagrams of PXRD, IR, TG and additional photoluminescence spectra, can be found in online version. CCDC 1546509 and 1546510 contain the supplementary crystallographic data for this paper. These data can be obtained free of charge via www.ccdc.cam.ac.uk/data_request/cif.

Acknowledgements This work was supported by the National Natural

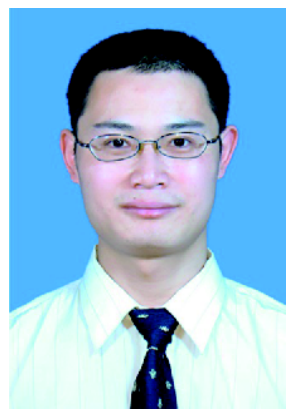

Xinhui Zhou received his Bachelor degree from Dalian University of Technology in 2001, his Master degree from Shantou University in 2006, under the supervision of Prof. Dan Li and his PhD degree from Nanjing University in 2009, under the supervision of Prof. Jinglin Zuo. He joined the Institute of Advanced Materials (IAM), Nanjing University of Posts \& Telecommunications in 2009. His research interests are focused on the MOF-based luminescent sensing materials.
Wei Huang received his PhD degree from Peking University in 1992. In 1993, he began his postdoctoral research at the National University of Singapore. In 2001, he was appointed as a chair professor of Fudan University, where he founded and chaired the Institute of Advanced Materials (IAM). In 2006, he was appointed vice president of Nanjing University of Posts \& Telecommunications. In 2012, he was appointed the president of Nanjing Tech University. Now, he is the vice president of Northwestern Polytechnical University. He was elected as Academician of the Chinese Academy of Sciences in 2011. His research interests include organic/plastic materials and devices, nanomaterials, and nanotechnology.

\section{基于含铺金属-有机框架的比率turn-on型铝离子发光传感器}

周馨慧 ${ }^{*}$, 程嘉荟 ${ }^{1}$, 李亮 $^{1}$, 陈强 ${ }^{1}$, 游宇健 $^{1}$, 肖洪平 ${ }^{2}$, 黄维 $^{1,3^{*}}$

摘要 本文制备了三种同构镧系金属有机框架材料 $\left(\mathrm{Me}_{2} \mathrm{NH}_{2}\right)\left[\mathrm{Ln}_{2} \mathrm{~L}_{2}\left(\mathrm{NO}_{3}\right)_{2}\left(\mu_{3}-\mathrm{OH}\right)\left(\mathrm{H}_{2} \mathrm{O}\right)\right] \cdot 2 \mathrm{H}_{2} \mathrm{O} \cdot 2 \mathrm{DMA},\left(\mathrm{Ln}=\mathrm{Eu}(\mathbf{1}), \mathrm{Gd}(\mathbf{2}), \mathrm{Tb}(3), \mathrm{H}_{2} \mathrm{~L}=9\right.$ 甲基-9-羟基-2,7-芴二羧酸, $\mathrm{DMA}=$ 二甲基乙酰胺). 研究结果显示它们具有三维阴离子型框架结构, 该结构可简化为含有单一的 8 连接型 节点的体心立方 $(\mathrm{bcu})$ 型拓扑结构. 化合物 $\mathbf{1}$ 表现出基于配体的苂光发射峰以及铕离子的特征苂光发射峰. 苂光实验表明在DMF溶液中 $\mathrm{Al}^{3+}$ 会明显增强配体的荧光强度, 而对 $\mathrm{Eu}^{3+}$ 的苂光强度影响却很小, 这使得 $\mathbf{1}$ 成为了优秀的比率式发光 $\mathrm{Al}^{3+}$ 传感器. 在 $\mathrm{Al}^{3+}$ 浓度处于

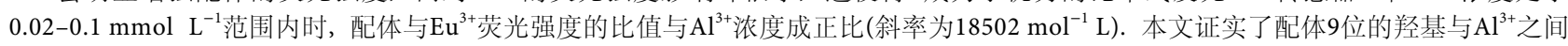
的相互作用是引起配体荧光增强的主要原因. 